\title{
New detection of the occurrence of trypanosomiasis in a bovine herd in a rural property in the state of Bahia/BA - case report*
}

\section{Nova detecção da ocorrência de tripanossomíase em rebanho bovino em propriedade rural no estado da Bahia/BA - relato de caso}

\author{
Felipe Gaia de Sousa, ${ }^{* *}$ Rogério Carvalho Souza, ${ }^{* * *}$ Leandro Silva de Andrade ${ }^{\star \star * *}$
}

\begin{abstract}
This report aims to discuss the occurrence of protozoan infestation in a Girolanda cattle herd in the state of Bahia / BA. Bovine trypanosomiasis is a severe disease that is harmful to cattle, inducing large productive and economic losses. The animals are affected by protozoa of the genus Trypanosoma spp., giving rise to infestations in the vast majority of them in a silent and lasting way. In the Bahian rural property described, $10 \%$ of adult cows died and the rest of the animals showed clinical signs of anemia, drop in milk production, low body score, apathy, among others. Among the information obtained through the farm manager, who helped in the diagnosis and in ordering tests for the respective disease were: purchase of cattle from the region of the state of Minas Gerais and dubious management of oxytocin for improvements in milk production (suspected shared needles). Faced with the suspicion and in conjunction with the information obtained, laboratory tests and molecular tests were carried out to confirm the suspicion. After the examinations, it was found that the animals were affected by protozoa of the genus Trypanossoma vivax. The animals were treated with volume replenishers and drugs such as isometamidium chloride in a single dose calculated according to the body weight.
\end{abstract}

Keywords: cattle, Trypanossoma spp., productive and economic losses, protozoan disease.

\section{Resumo}

O presente relato tem por objetivo discorrer sobre a ocorrência da infestação protozoária em um rebanho bovino da raça Girolanda no estado da Bahia/BA. A tripanossomíase bovina é uma doença severa e prejudicial aos bovinos, induzindo-os a grandes perdas produtivas e econômicas. Os animais são afetados por protozoários do gênero Trypanosoma spp., dando origem a infestações em sua grande maioria de forma silenciosa e duradoura. Na propriedade rural baiana descrita, $10 \%$ das vacas adultas morreram e o restante dos animais apresentava sinais clínicos de anemia, queda da produção leiteira, baixo escore corpóreo, apatia, prostração, entre outros. Dentre as informações obtidas através do gerente da fazenda, que auxiliaram no diagnóstico e na requisição de exames para a respectiva doença estavam: compra de bovinos da região do estado de Minas Gerais e manejo duvidoso de ocitocina para melhorias na produção leiteira (suspeita de agulhas compartilhadas). Diante da suspeita e em conjunto com informações obtidas, foram realizados exames laboratoriais e testes moleculares para confirmar a suspeita. Após a realização dos exames, constatou-se que os animais estavam acometidos por protozoários do gênero Trypanossoma vivax. Os animais foram tratados com repositores de volume e fármacos como o cloreto de isometamidium em uma única dose calculada de acordo com o peso corpóreo.

Palavras-chave: bovinos, Trypanossoma spp., perdas produtivas e econômicas, enfermidade protozoária.

\section{Introduction}

Bovine trypanosomiasis is characterized by infection by protozoa of the genus Trypanosoma spp., causing numerous productive and economic losses. With wide spatial distribution, the disease has spread throughout the country with prevalence in certain regions such as the state of Minas Gerais. As it appears silently, it enters and perpetuates the herd in an unnoticed way, inducing severe bodily and productive depletion. Those affected have variable symptoms depending on the degree of infestation.
Transmission occurs through mechanical sources, whether they are fomites and / or vectors such as hematophagous insects. It is believed that the main route of dissemination is related to the management of oxytocin, in addition to the use of shared syringes in other procedures.

The diagnosis is obtained through the association of data such as: history; anamnesis and clinical-visual evaluation; laboratory tests such as hematocrit and parasitological tests, indirect immunofluorescent antibody test (IFAT) and polymerase chain reaction $(\mathrm{PCR})$. Treatment is based on the use of diminazene

\footnotetext{
${ }^{*}$ Recebido em 2 de junho de 2021 e aceito em 23 de setembro de 2021.

${ }^{* *}$ Veterinarian. Pontifícia Universidade Católica de Minas Gerais - PUC Minas/MG. Departamento de Medicina Veterinária; Betim; Minas Gerais - Brazil.

${ }^{* * *}$ Adjunct Professor IV in the area of Production Medical Clinic - Pontifícia Universidade Católica de Minas Gerais - PUC Minas/MG; Departamento de Medicina Veterinária; Betim; Minas Gerais - Brazil.

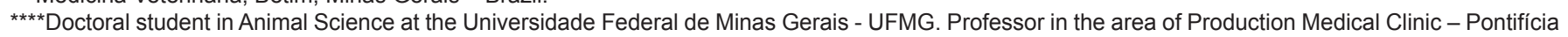
Universidade Católica de Minas Gerais - PUC Minas/MG; Departamento de Medicina Veterinária; Betim; Minas Gerais - Brazil.

Correspondence author: fgaias@outlook.com
} 
aceturate or isometamidium chloride (CONSTABLE et al., 2017). In view of the reduced and / or absent number of studies described and published for the disease in the state of Bahia / BA, the present report aims to report the occurrence of trypanosomiasis in a dairy herd on a rural property in the respective state and to correlate it with information available in the literature.

\section{Case Report}

In a rural property in the southwestern region of the state of Bahia, due to the occurrence of countless deaths and productive losses, several professionals were called in to determine the cause and establish a therapeutic management. However, all the professionals summoned, after attempts at diagnosis, were unable to determine what was the reason for the problem on the property. Thus, a new team of veterinarians was convened (May 2019) to provide consultancy and services, in addition to seeking tools to improve the workforce installed on the farm.

Among the objectives of the present visit were: to evaluate the cases of mortality, to inspect the herd, the environment and the routines developed on the farm, to perform laboratory exams of egg count per gram of feces, number of oocysts per gram of feces, blood smears, microhematocrit, thick drop, Woo parasitological test and buffy coat. Thus, the services developed in the respective location aimed at a general explanation of the situation faced by the animals. The problem faced on this farm affected the category of adult cows, a fact that determined the call and going to the place, since these represented an important economic and productive component.

The farm is intended for the breeding of Girolanda dairy cattle and the animals present are conditioned by age groups, being: calves, adult cows, dry cows, in production and discard cows. Herd feeding was based on sorghum silage, concentrates and grazing in Brachiaria sp. During the anamnesis, the manager informed that the situation they were subjected to was based on the occurrence of death in $10 \%$ of animals of the breed. The animals were weak and prostrate, with a history of progressive weight loss, absence and / or reduced food and water intake, abortions, among others. In addition, he also mentioned that months ago, they bought animals from the central region of Minas Gerais, close to the regions of Pompéu and Martinho Campos. He reported that, on the farm, they use oxytocin to improve milking management, but without further details. In the vicinity of the property, there is a sugarcane plant that attracted flies, but vector control was done by wearing earrings.

The manager reported that other professionals visited the property and prescribed applications of antibiotics, antiinflammatories, electrolytics, but they did not autopsy the dead animals. However, he says that only one professional collected blood samples for blood count and sent part of them for trypanosomiasis analysis. Regarding the autopsy findings, he did not report on the conclusions obtained by the professional. Of the 20 samples sent, 4 came positive for Trypanosoma vivax (T. vivax). The fact described above was only reported after the anamnesis and clinical evaluation of the herd were carried out. However, the professional was unable to determine the final cause as trypanosomiasis, since more diagnostic forms are needed for real proof, and neither an effective drug therapy and the animals continued to worsen the clinical picture.
The clinical examination was performed on 100 animals on the property. It was observed that the dry cows in general had good health and body conditions, with an average score of 3.25 on inspection. Some animals showed changes in the hoof. In the dry cows of the cleared paddock, some animals on inspection were slightly more prostrate and / or with a hoof problem, but the vast majority of the inspection also showed good general health conditions and body score (average 3.25). In the lot of cows under treatment, generally observed, there were animals with a large number of ectoparasites, poor body condition (average 1.5 - 2.0), visible weight loss, many animals being treated for various diseases such as mastitis, chronic pneumonia and otitis.

Laboratory tests of hematocrit $(\mathrm{Ht} \%)$, Woo and thick drop were performed on a sample of the bovine population. The results obtained were: average of $25.6 \mathrm{Ht} \%$, Woo and thick drop negative for $T$. vivax. In the blood smear, no presence of Anaplasma sp., Babesia sp. and T. vivax. Through the buffy coat exam, no evidence of alteration was observed. In the egg count per gram of feces and oocysts per gram of feces exams, the average count was 100 eggs for helminths in general and 150 oocysts of Eimeria sp.

In view of the condition experienced on the farm, it was observed that there was an absence of data related to the health of the herd; absence of trained staff for current health challenges; management of hoof problems and failures in the preventive measures adopted (footbath, lack of trained staff). In addition, low body score (average of $2.25-2.5$ ) in $40 \%$ of farm animals, in addition to unevenness; loss of 1.0 average body condition of the cows between pre and postpartum; mild anemia in $40 \%$ of the animals evaluated; management of oxytocin as a high risk factor for several health events due to the great possibility of not using individual syringes for cows.

As much as the problems were detected, there was still no determination of a definitive diagnosis. In addition, other problems such as changes in the hoof and ketosis could be seen and could make it difficult to determine one of the final diagnoses, since the property was being affected by other causes. Thus, associating the anamnesis with the clinic in addition to the following information: the property had an outbreak of chronic disease; several animals with anemia; oxytocin management performed in a doubtful manner; history of purchase of animals in previous months; pregnancy loss; productive drop (loss of 1.82 liters / cow at the end of lactation peak); in addition to the drop in score and weight loss; allowed new hypotheses to be formulated.

In view of this, the main hypothesis was the presence of trypanosomiasis, but concluding a diagnosis with only anamnesis and clinical vision data is not ideal, since they do not provide subsidies for this. Thus, more sensitive tools were used, such as molecular tests (indirect immunofluorescent antibody test IFAT and polymerase chain reaction - PCR). In addition, these are essential for confirming diagnosis and discarding differential diagnoses. IFAT was performed on 100 animals, 7 of which were positive for T. vivax (titration 1:40). The PCR test was performed in 30 animals, of these, in 3 cattle the samples were positive for the same protozoan.

In view of the results of the examinations performed on the property, associated with the data obtained during the anamnesis and clinical examination, one of the diagnoses of the property was determined to be trypanosomiasis by T. vivax. 
In addition, recommendations were given to the manager for improvements, since several areas had irregularities according to location, operation and maintenance, predisposing the animals to various diseases. Among the recommendations were: creation of disease monitoring programs; correct and persistent treatment; among others.

One of the orientation given was based on the correct management of oxytocin, with the use of individual syringes / needles for each animal, since it was strongly determined in the hypothesis that the disease had progress on the property through shared syringes. Due to the diagnostic confirmation, among the drugs and volemic replenishers that were prescribed was isometamidium chloride at a dose of $1 \mathrm{mg} / \mathrm{kg}$ in a single dose.

\section{Discussion}

Trypanosomiasis is a hemoparasitosis originated through infestation by protozoa of the genus Trypanosoma spp., affecting numerous species and promoting clinical conditions of vast damage. Among the pathogenic agents, T. vivax is the most common for cattle. The disease can present itself in two forms, clinical and subclinical, however both promote conditions of intense productive and economic damage (BASTOS et al., 2017; GOMES et al., 2021). The subclinical form may explain, in part, the great ease of progression and chronicity of the disease, since the animals with the respective presentation do not show signs that can generate perceptible warning signs.

The transmission of the disease is diverse and restricted to specific regions. Cases of African bovine trypanosomiasis are associated with the presence of tsetse flies (Glossina palpalis) (BASTOS et al., 2017). However, transmission in Brazil is associated with the presence of flies of the genus Stomoxys and Tabanus, and through contaminated fomites (BASTOS et al., 2017; GOMES et al., 2021). The clinical signs presented by the animals were in accordance with the data described in the literature (CARVALHO et al., 2008; BASTOS et al., 2017; Reis et al., 2019; GOMES et al., 2021). It is noteworthy that the drop in milk production and the fever shown in the report do not clearly indicate whether they were caused by the disease, since the property had other diseases (eg bovine podiatry, ketosis) that could cause the above changes.

The introduction of the disease in herds is associated with the purchase / sale of animals from areas with the presence of cases (CADIOLI et al., 2012; BASTOS et al., 2017). In the present report, the owner reported that they had recently purchased cattle from regions of Minas Gerais, especially the central area. The state of Minas Gerais is one of those reported with detection and dissemination of the disease (CARVALHO et al., 2008). The animal trade without more data about possible diseases allows the expansion of these to free areas, accelerates the progression process and makes possible the occurrence of outbreaks (CADIOLI et al., 2012; PEREIRA et al., 2018).

It is believed that the focus of the disease's origin in the respective property in Bahia is related to the purchase of cattle made by the owner in Minas Gerais. The same fact may have been the reason for the introduction of Trypanosoma on a property in the state of Goiás after the purchase of 8 cows at an auction, in which they were from the Triângulo Mineiro region (BASTOS et al., 2017). BASTOS et al. (2017) still report that 16 days after purchase, some animals from this auction started to show symptoms suggestive of trypanosomiasis. The hypothesis of vectorial transmission was ruled out, as much as the property is close to sugarcane plant residues, the animals use earrings for vector control.

One of the major disseminating forms of the disease is the sharing of syringes and needles for carrying out various procedures, especially for the management of oxytocin (REIS et al., 2019). At the reported property, the manager reported using oxytocin to increase milk production, but did not provide details on how the process was done. It is noteworthy that several properties use the hormone as a way of improving lactational function. Oxytocin is a hormone produced by the neurohypophysis and has several functions such as the descent of milk, among others (BASTOS et al., 2017).

The progression of the disease in the reported property is strongly related to the sharing of syringes during the process of oxytocin administration, since calves and cows that were not subjected to the use of the hormone did not present symptoms and did not die. The sharing of syringes is one of the main forms of transmission of the disease, since the passage of protozoa occurs from an affected animal to a healthy one (BASTOS et al., 2017). In addition, the management of oxytocin is configured as a high risk factor for several health events such as phlebitis, pneumonia, endocarditis, septicemia, among others. Reis et al. (2019) observed that among the 11 positive (11/30) farms for trypanosomiasis, $10(10 / 11)$ of them presented syringe sharing as the main transmissible source.

In order to obtain a diagnosis of the occurrence of trypanosomiasis, it is necessary to perform a set of laboratory tests, which associated with the history and clinical examination, allow a better characterization of the condition present on the property. In addition, the association of exams allows the determination of a more assertive diagnosis, excluding differential diagnoses (JUNIOR et al., 2019). Among the differentials, we can mention anaplasmosis and babesiosis, since they can cause symptoms on the affected animal similar to those caused by Trypanosoma spp. Hematological analyzes are essential for the general evaluation of the herd, allowing the determination of the degree of anemia if present.

Considering the diagnostic forms, two present great prominence, being the parasitological and the molecular methods. Parasitological methods include the Woo method (hematocrit centrifugation), blood smears, thick drop,"buffy coat". Molecular analyzes can be obtained through PCR, real-time PCR, IFAT, Enzyme-Linked Immunosorbent Assay (ELISA). In the present report, the animals were submitted to all the parasitological methods described above. The observed values were: average hematocrit of $25.6 \%$; thick drop and buffy coat without changes.

Direct parasitological methods have less sensitivity when compared to other methods, since to prove the infestation high parasitic levels are necessary. Direct methods are characterized by having a lower detection capacity during chronic phases, since protozoa are more difficult to detect in phases of low parasitemia or aparasitemic periods (JUNIOR et al., 2019). However, they can determine the presence of the parasite in acute stages of infection. This fact may be associated, in part, with the progression of the disease and the ability of the protozoa to evade the immune system. 
Onyilagha and Uzonna (2019) argue that parasites use different ways to escape the immune system, ensuring that they perpetuate and complete their differentiation. The evasion strategy is related to some factors such as: specific properties of the parasite (eg antigenic variability) and the ability of the defense cells to prevent them (ONYILAGHA; UZONNA, 2019). According to Gomes et al. (2021) "it should also be noted that asymptomatic animals, or those with subclinical disease, might test negative in parasitological exams because in the asymptomatic phases the hemoparasite may be present in the extravascular regions such as the lymph nodes and not in the blood".

In view of the condition that parasitological tests are less sensitive and in association with the advancement of the clinical condition of the animals on the reported property, it was determined that more specific tests with PCR and IFAT would be necessary. Molecular tests have better detection capabilities of the protozoan, especially in patent and subpatent phases (REIS et al., 2019; JUNIOR et al., 2019; GOMES et al., 2021). However, Junior et al. (2019) affirm that no matter how the techniques present great benefits, they can present false negative results mainly when the number of parasites is below the detectable values.

In the present report, the molecular results were: $7 / 100$ animals $(7 \%)$ in the IFAT test (1:40 dilution) and $1 / 30$ animals $(3,3 \%)$ in the PCR showed a positive result for $T$. vivax, demonstrating the ability of molecular examinations to better evidence the presence of the parasite when compared to smear examinations for example. Gomes et al. (2021) carried out a study with the objective of detecting the presence of $T$. vivax in three tropical areas (Ibirataia, Prado and Jucuruçu) in the south of the state of Bahia by means of blood smear and PCR tests. The authors

\section{References}

BASTOS, T.S.A.; FARIAA.M.; MADRID, D.M.C.; BESSA, L.C.; LINHARES, G.F.C.; JUNIOR, O.L.F.; SAMPAIO, P.H.; CRUZ, B.C.; CRUVINEL, L.B.; NICARETTA, J.E.; MACHADO, R.Z.; COSTA, A.J.; LOPES, W.D.Z. First outbreak and subsequent cases of Trypanosoma vivax in the state of Goiás, Brazil. Brazilian Journal of Veterinary Parasitology, v. 26, n. 3, p. 366-371, 2017.

CADIOLI, F.A.B.; BARNABÉ, P.A.; MACHADO, R.Z.; TEIXEIRA, M.C.A.; ANDRÉ, M.R.; SAMPAIO, O.L.F.; TEIXEIRA, M.M.G.; MARQUES, L.C. First report of Trypanosoma vivax outbreak in dairy cattle in São Paulo state, Brazil. Brazilian Journal of Veterinary Parasitology, v. 21, n. 2, p. 118-124, 2012.

CARVALHO, A.U.; ABRÃO, D.C.; FACURY FILHO, E.J.; PAES, P.R.O.; RIBEIRO, M.F.B. Occurrence of Trypanosoma vivax in the state of Minas Gerais. Arquivo Brasileiro de Medicina Veterinária e Zootecnia, v. 60, n. 3, p. 769-771, 2008.

CONSTABLE, P.; HINCHCLIFF, K.W.; DONE, S.; GRUENBERG, W. Systemic and Multi-Organ Diseases. In: CONSTABLE, P.D.; HINCHCLIFF, K.W.; DONE, S.H.; GRÜNBERG W. (eds.) Veterinary Medicine: A textbook of the diseases of cattle, horses, sheep, pigs and goats - 2 vol. St. Louis: Elsevier, 2017, p. 2150-2156. collected 623 samples and observed that: $81.1 \%$ (505/623) were negative for smear and PCR; $18.6 \%$ (116/623) were negative for smear, but positive for PCR; $0.3 \%$ (2/623) were positive in both tests. The authors were able to confirm that PCR exams are more sensitive to detection when compared to blood smears (18.6\%) (GOMES et al., 2021).

The treatment prescribed with isometamidium chloride at a dose of $1 \mathrm{mg} / \mathrm{kg}$ is in accordance with Constable et al. (2017) that indicates the use of trypanocide for therapeutic management at a dose of $0.25-1 \mathrm{mg} / \mathrm{kg}$ body weight. In addition, it may be necessary to combine it with other drugs and volemic replenishers (CONSTABLE et al., 2017).

\section{Conclusions}

In light of the above, it is becoming increasingly clear the serious damage that trypanosomiasis causes in those affected, especially cattle. By entering the rural properties in a silent, progressive and harmful way, they promote great infestations inducing death, loss of body score, drop in milk production, anemia, among others. Increasingly attentive views on the part of the professionals to the clinical signs presented by the herd are fundamental so that suspicions of the occurrence of the disease can be investigated with greater diligence. Increasingly sensitive diagnostic tools should be put into practice when bovine trypanosomiasis is suspected. It is increasingly necessary to have a more defined and structured knowledge of the owners about the disease and the dangers that surround it. In addition, further studies are needed to determine mechanisms for the occurrence and perpetuation of trypanosomiasis in the country, especially in the state of Bahia / BA.

GOMES, H.C.S.F.; GENIPAPEIRO, I.L.J.; ANDRADE, F.T. First detection of Trypanosoma vivax in cattle in the state of Bahia, Brazil, based on parasitological and molecular analyzes. Semina: Agrarian Sciences, v. 42, n. 3, p. 2065-2072, 2021.

JUNIOR, O.L.D.; SAMPAIO, P.H.; GONÇALVES, L.R. Comparison of convetional and molecular techniques for Trypanosoma vivax diagnosis in experimentally infected cattle. Brazilian Journal of Parasitology, v. 28, n. 2, p. 203-209, 2019.

ONYILAGHA, C.; UZONNA, J.E. Host Immune Responses and Immune Evasion Strategies in African Trypanosomiasis. Frontiers in immunology, v. 10, p. 1-12, 2019.

REIS, M.O.; SOUZA, F.R.; ALBUQUERQUE, A.S. Epizootic infection by Trypanosoma vivax in cattle from the state of Minas Gerais, Brazil. Korean Journal of Parasitology, v. 57, n. 2, p. 191195, 2019. 